\title{
INCREASE IN SOCIAL ACTIVITY OF CITIZENS ON THE BASIS OF GRANT SUPPORT OF RURAL INITIATIVES
}

\author{
Alexander I. Bogatchev \\ All-Russian Research Institute of Social Development of Rural Areas, Orel State Agrarian University, Orel, Russia
}

The article is devoted to the problems of development of social activity of population. The low activity of local population is now characterized by the following social trends: aloofness from public life, individualism, leading-strings mentality, consumer attitude, legal nihilism. The characteristic of the main reasons for the current situation is given in the article. It is noted that one of the effective tools to attract social investment and development is a grant support for local initiatives, which plays an important role in increasing the social activity of population. This article focuses on the development of grant support in the rural areas at the modern stage. The author analyzed the current status of grant support of rural initiatives in Russia and the Orel region. It is noted that the grant support has great potential, although it is at an early stage of its development. In the conclusion, actions for the development of social activity at the local level are planned.

Keywords: sustainable development, rural areas, grants support, local initiatives, Orel region

\section{Introduction}

The level of social and economic development of the territory, the quality of life and comfort of accommodation of population in a concrete municipality in many respects depend on completeness and quality of the services rendered by the authorities and the organizations in various spheres of activity of those settlements. However, in many respects it depends also on the degree of inhabitants' activity in the development and decision-making on providing comfort and quality of life, on extent of their participation in these processes in their own settlements.

The solution of the problem of increase in social activity of population acquires special relevance in the conditions of development of local selfgovernment and reforming in the rural zone. However, the lack of sufficient material and financial resources for the development of rural municipalities complicates feelings of participation in changes outside own yard, and often brings to naught all efforts on development of the rural zone.

The complex All-Russian research "Conditions of Increase in Social Activity of Citizens in the Solution of Local Problems" conducted in 2008 at the initiative of the All-Russian Council of local self-government and the Civic chamber of the Russian Federation testifies to rather low share of participation of the population in the questions of local life solution. In particular, more than $60 \%$ of respondents are sure of impossibility to affect somehow the life in the settlement, including through participation in self-government (Empirical researches..., 2008).

The main reasons constraining the activity of citizens were: the lack of time, the lack of an initiative from the outside, including from the authorities, the dependency mentality of the population, disbelief in the opportunity to impact on the decisions-making, difficult social and economic situation in the municipality.

Now, the situation changes for the better. The need to be not only heard, but also the desire to become active participants of different projects implementation has been observed in the large part of municipalities (The report "About sustainable..., 2014).

Ultimately, the level and features of activity of population according to the solution of the questions of local value are caused by the complex of socioeconomic, political, organizational, cultural, demographic, psychological and other factors. The individual factors do not determine the particular activity of the population, and the interaction can both strengthen and weaken the latest one (Galchenko, 2013).
In this regard it is urgent to implement the complex of actions for increasing the social activity of local population and its active attraction to the participation in the local self-government.

\section{Material and methods}

The world practice demonstrates that there is a set of approaches and models of attraction of resources for providing the activity of citizens. One of the effective instruments for attracting investment into the social sphere and development of social activity of the population is a grant support of local initiatives (Bogatchev and Polukhina, 2015). According to the director of Rural Development and Social Policy Department of the Ministry of Agriculture of the Russian Federation, Toropov D. I., financing of the projects of economic and social development of rural areas by means of grants supplements the forms of financing the development of the territories (Toropov).

The statistical and economic analysis of the grant mechanism application to support the local initiatives of rural citizens on the territory of the Russian Federation and at the regional level (in the example of the Orel region) was the basis of the conducted research. The main objective of this analysis is to determine the effectiveness of its application and to establish the impact of support on the development of rural areas, as well as to develop the proposals for increasing the community commitment.

\section{Grant support of the local initiatives as the tool for rural development}

The actions for grant supports of local initiatives of rural citizens have been implemented in the territory of the Russian Federation since 2014. The Support is carried out within the Federal target program "Sustainable Development of Rural Areas for 2014-2017 and for the Period till 2020". Grants are provided on the gratuitous and irrevocable basis to the local government or to the territorial public self-government of the rural settlement on the implementation of socially significant noncommercial projects with participation of the citizens living in the rural zone. The priority areas of support have been allocated as follows:

$\square$ recreation development, the development of sports and children's playgrounds (the projects on creation and arrangement of parks, embankments, beaches and other public recreation areas, sports and children's playgrounds); 
$\square$ preservation and restoration of natural landscapes, historical and cultural monuments (projects on cleaning of reservoirs, coastal zones, forest plantings, preservation and restoration of objects of cultural heritage);

$\square$ support for the national cultural traditions, national arts and crafts (projects on creation of the museums of country life, traditional arts and crafts, organization of reviews festivals of interethnic culture, support of information projects on promoting national cultural traditions).

Projects can be developed by the village dwellers and their associations, rural municipalities and the economic entities operating in their territory.

The main objectives of the rural people initiatives grant support are as follows:

$\square$ intensification the participation of the rural population in the solution of matters of local significance;

$\square$ mobilization of material, labour and financial resources of certain citizens and their associations, rural municipalities and the economic entities operating in their territories for local development;

$\square$ consolidation of local rural communities in the solution of the questions on improvement the settlements and improvements of the environment and the social habitat, participation in the development of plans for perspective development of rural settlements and formation of favourable social and psychological climate in the village (The federal target program..., 2013).

The size of the grant makes no more than $60 \%$ of the total cost of the project and cannot exceed the sum of 2 million rubles. Other part is financed by the local budget, and also an obligatory contribution of citizens, individual entrepreneurs and legal entities in implementation of the project.

During the period of implementation of the FTP "Sustainable development of rural areas for 2014-2017 and for the period till 2020" it is supposed to enable the realization of 571 projects of local initiatives of the citizens who live in the rural areas and got grant support. Financial support of the implementation of the above said direction is about 1.37 billion rub. (The federal target program..., 2013).

Projects to support the local initiatives get the liveliest response among the population, showing its viability in dealing with specific critical issues with the direct participation of the rural population (The report "About sustainable..., 2014).

Thus, according to the Ministry of Agriculture 207 million rub. was actually financed for the implementation of grant support measures for the local initiatives of citizens living in rural areas in 2014, including 53.6 million rubles which has been allocated from the federal budget, 91.2 million rubles from the consolidated budget of the Russian Federation subjects, 62.3 million rubles. from the non-budgetary sources. 174 projects of civic initiatives received the support against 95 provided by the state program. Implementation of the projects was carried out in 24 regions of Russia, of which 164 projects for the creation and arrangement of recreation areas, sports and children's playgrounds, 5 projects in the field of conservation and restoration of natural landscapes, historical and cultural monuments, 5 projects to support national cultural traditions, folk arts and crafts. The most active participants in the activities of grant support of rural people initiatives was the Ulyanovsk region (60 projects), the Altai Krai (24 projects), the Vologda, Kemerovo and Irkutsk regions (13, 11 and 10 projects, respectively) (The report of the Department..., 2014).

In 2015, 524 projects from 33 subjects were announced for grants to support local initiatives of rural citizens. The total estimated cost of the projects was 444.5 million rubles, of which the grant funds (funds from the federal and regional budgets) accounted for 259.6 million rubles, including $117 \mathrm{mln}$. rub. from the Federal budget. According to the results of the selection, 313 projects have received the support (Toropov).

\section{State of affairs of grant support development in the Orel region}

Grant support for local initiatives of rural people in the Orel region is conducted in accordance with the regional program "Sustainable development of rural areas of the Orel region, 2014-2017 and the period up to 2020" and Decree of the Government of the Orel region no. 247 from 28. 8. 2014 called " 0 n the procedure providing subsidies to the budgets of municipal formations of the Orel region for co-financing of measures to grant support of the local initiatives of citizens living in rural areas of Orel region. "The total amount of funding for the state program event is planned in the amount of $11 \mathrm{mln}$. rub., including $6.6 \mathrm{mln}$. rubles of grants (funds from the federal and regional budgets). The expected result of the federal program on the territory of the Orel region is the implementation of 22 projects of local initiatives of citizens living in the rural areas who have received grant support (projects for the promotion and popularization of achievements in the development of rural areas).

According to the results of the final selection by the Ministry of Agriculture of the Russian Federation in 2014 the grants to fund local initiatives were provided to the budgets of the three municipalities of the Orel region for the implementation of the following projects:

$\square$ outfitting of a children's playground in the village of Korsakovo, Korsakov district (grant amount of 120,000 rubles);

$\square$ outfitting of the sports playground in the village of Pankovo, Pankovski rural settlement area in Novoderevenkovsky district (138,000 rubles);

$\square$ restoration and renovation of brotherly burial places of the Soviet soldiers which is called "Remember all names" in the village of Kalineevo, Telchensky rural settlement, Mtsensk district $(354,000$ rubles).

The total amount of financing was 1020,6 thousand rubles (against 928 thousand rubles according to the reached Agreement) from which at the expense of a grant was 612 thousand rubles. At the expense of means of the federal budget was 300 thousand rubles, 312 thousand rubles were financed from the regional budget. Managed to reach the increase in the financing due to the growth of the raised funds from the local budget for $60.27 \%$

Table 1 Parameters of the Federal Program "Sustainable development of rural areas" regarding the actions for grant support of local initiatives

\begin{tabular}{|l|c|c|c|c|c|c|c|c|}
\hline & 2014 & 2015 & 2016 & 2017 & 2018 & 2019 & 2020 & Total according to the state program \\
\hline The total amount of financial support, mIn. rub. & 190 & 137.9 & 131 & 180.7 & 210.3 & 243.2 & 279.3 & 1372.4 \\
\hline including from means of the federal budget & 95 & 95 & 90.3 & 124.5 & 144.9 & 167.6 & 192.5 & 909.8 \\
\hline $\begin{array}{l}\text { from means of the consolidated budgets of territorial subjects } \\
\text { of the Russian Federation }\end{array}$ & 95 & 42.9 & 40.7 & 56.2 & 65.4 & 75.6 & 86.8 & 462.6 \\
\hline Number of implemented projects for local initiatives, in units & 95 & 65 & 59 & 76 & 83 & 92 & 101 & 571 \\
\hline
\end{tabular}


Table 2 Financing of the projects of citizens' initiatives on a grant basis in the Orel region, 2014

\begin{tabular}{|c|c|c|c|}
\hline & $\begin{array}{l}\text { Outfitting of a children's playground } \\
\text { in the village of Korsakovo }\end{array}$ & $\begin{array}{l}\text { Outfitting of the sports playground } \\
\text { in the village of Pankovo }\end{array}$ & $\begin{array}{l}\text { Restoration and renovation of brotherly burial places } \\
\text { of the Soviet soldiers in the village of Kalineevo }\end{array}$ \\
\hline $\begin{array}{l}\text { The general expenses on the project, } \\
\text { including for the account of: }\end{array}$ & 200 & 230.6 & 590 \\
\hline Grant & 120 & 138 & 354 \\
\hline $\begin{array}{l}\text { of which: } \\
\text { - federal budget } \\
\text { - regional budget }\end{array}$ & $\begin{array}{l}61.2 \\
58.8\end{array}$ & $\begin{array}{l}70.3 \\
67.7\end{array}$ & $\begin{array}{l}180.5 \\
173.5\end{array}$ \\
\hline Local budget & 30 & 46.3 & 118 \\
\hline Contribution of citizens, JVs and legal entities & 50 & 46.3 & 118 \\
\hline $\begin{array}{l}\text { of which } \\
\text { - citizens } \\
\text { - JV (joint ventures) } \\
\text { - legal entities }\end{array}$ & $\begin{array}{c}5 \\
10 \\
35\end{array}$ & $\begin{array}{l}20 \\
20 \\
6.3\end{array}$ & $\begin{array}{l}45 \\
28 \\
45\end{array}$ \\
\hline
\end{tabular}

(237.2 thousand rubles against 148 thousand rubles) and non-budgetary sources for $1.96 \%$ (171.3 thousand rubles against 168 thousand rubles). Key parameters of financing of the specified projects are presented in table 2 .

In 2015 in the territory of Orel region none of the projects was implemented within the actions for grant support of rural initiatives that, first of all, is explained by the sequester of the regional budget and the lack of the allocated funds for the actions of grant support.

In 2016, seven applications for receiving grant support of rural initiatives were submitted to the Department of agricultural industry of the Orel region. Among them there are projects on the creation and arrangement of the children's playground in the village of Shalilovo, the creation and arrangement of the recreation area with the forester's track in the settlement of Kolpny and some other. In general, in the current year 1.2 million rubles were allocated for support of local initiatives from the regional budget, having provided the general level of financing of 1.8 million rubles (667.3 thousand rubles was allocated from the federal budget).

Grant support on realization of the local initiatives will be received by inhabitants of 6 municipalities of the region: the Krasnozorensky, Kromsky, Livensky, Novoderevenkovsky, Novosilsky and Trosnyansky districts.

\section{Results, discussion and the main conclusions}

The conducted researches showed that grant support of the local initiatives certainly cannot resolve all existing issues. However, it can act as the means capable to start the mechanism of further active participation of citizens in the life of their hometown, the settlement and village.

Change of the level and the nature of social activity demands time and considerable efforts. Therefore it is necessary to continue work oriented on the support of the active people living in the rural zone because the activity increase of peasants and social development of the locality act as the basis of preservation and development of a village.

For the development of social activity at the local level it is necessary to implement a set of measures, among which are the following:

$\square$ to improve the system of local self-government and providing regional authorities with necessary resources and opportunities for support of social activity on the basis of entering of the corresponding amendments into the legislation;

$\square$ to strengthen the system of legal education of citizens, to inform them on opportunities of participation in the solution of questions of local value, to provide citizens with necessary methodical recommendations and consultations; $\square$ to carry out promotion of values of social responsibility via various channels, to inform citizens on effective examples of social activity, to create the system of encouragement of the best social activists and the municipalities which most effectively work with the public, to cultivate patriotism and feeling of participation in life of the settlement;

$\square$ to create complex system on the education of new leaders of local self-government, and also the education of heads of municipalities and experts in the sphere of interaction with the public;

$\square$ to develop recommendations about creation of support system of public initiatives for municipalities.

$\square$ to involve more active the members of the media in development the social activity of local population.

\section{References}

BOGATCHEV, A. I. - POLUKHINA, M. G. 2015. Methodical approach to assessment of social development of rural territories. Science and education, 2015, no. 1.

GALCHENKO, V. V. 2013. Local self-government as institute of development of social activity of the population: the abstract of the thesis for the degree of the candidate of science, Moscow, 2013.

The report of the Department of rural development and social policy of the Ministry of Agriculture of the Russian Federation "About grant support of local initiatives of the citizens living in the rural area". Moscow, 2014.

The report "About sustainable development of rural areas of the Russian Federation". Moscow, Kremlin, 2014.

The government of the Orel region distributed more than 1,8 million rubles on grant support of local initiatives of villagers in 2016. [An electronic resource] the access Mode: http://orel-region.ru/index.php?head $=1$ \&unit $=7526$

TOROPOV, D. I. Experience of grant support of local initiatives of citizens. [An electronic resource] the access Mode: http://mcx-consult.ru/Articles/Details/1905

The federal target program "Sustainable development of rural areas for 2014-2017 and for the period till 2020" approved by the Resolution of the Government of the Russian Federation No. 598 of 13. 7. 2013. [An electronic resource] the access Mode: http:// base.garant.ru/70419016/\#5

Empirical researches of civil society: collection of materials of public hearings (24. 9. 2008). A. M. Lopukhin. 2008. M. Public chamber of the Russian Federation, p. 152.

\section{Contact address}

A. I. Bogatchev, PhD in Economics, All-Russian Research Institute of Social Development of Rural Areas, Orel State Agrarian University, director, 302019. Russia, Orel, General Rodin Str., 69, Phone: + 792028789 52, e-mail: bogatchev@inbox.ru 